\title{
HAYLAGE: A FORAGE CONSERVATION ALTERNATIVE
}

\author{
SILVA, Alex Lopes da ${ }^{1}$ \\ SANTOS, Betina Raquel Cunha dos ${ }^{1}$ \\ PERAZZO, Alexandre Fernandes ${ }^{2}$ \\ CESAR NETO, José Maria ${ }^{1}$ \\ SANTOS, Francisco Naysson de Sousa ${ }^{1}$ \\ PEREIRA, Danillo Marte ${ }^{1}$ \\ SANTOS, Edson Mauro
}

\begin{abstract}
SUMMARY: The objective was to cover and discuss the characteristics of haylage that makes it an alternative of forage conservation. The haylage is based on the dry matter content after a wilt process, then baled similar to hay and wrapped with plastic films in order to be conserved under anaerobic fermentation. The dry matter content after wilt exceeds $500 \mathrm{~g} \mathrm{~kg}^{-1}$. Conserved forages with high content of dry matter present stabilization at high $\mathrm{pH}$, which favors bacteria of the genus Clostridium. The $\mathrm{pH}$ of the haylage, because it has a high content of dry matter in its confection, limits the capacity of bacterial fermentation, it does not produce sufficient acid and becomes resistant to $\mathrm{pH}$ drops, this characteristic must be considered along with other factors. The preservation quality of haylage cut under the same conditions of the hay presents similar chemical composition, therefore, when the haylage is preserved under ideal conditions, it is an alternative to replace the hay. The definition and characteristics of haylage clearly expresses that it is an alternative conservation to hay and silage.
\end{abstract}

Keywords: Conservation. Dehydration. Fermentation. Forage.

\section{PRÉ-SECADO: UMA ALTERNATIVA DE CONSERVAÇÃO DE FORRAGEM}

\begin{abstract}
RESUMO: Objetivou-se abranger e discutir as características de pré-secado que lhes confere uma alternativa de conservação de forragem. O pré-secado é baseado no teor de matéria seca após um processo de murcha, em seguida enfardados semelhante ao feno e envolvidos com filmes plásticos, a fim de conservar sob fermentação anaeróbica. $\mathrm{O}$ teor de matéria seca após a murcha excede $500 \mathrm{~g} \mathrm{~kg}^{-1}$. Forragens conservadas com elevado teor de matéria seca conferem estabilização em $\mathrm{pH}$ alto, isso favorece bactérias do gênero Clostridium. $\mathrm{O} \mathrm{pH}$ do pré-secado, por possuir um alto teor de matéria seca na confecção, limita a capacidade de fermentação bacteriana, este não produz aácido suficiente e torna-se resistente a queda do $\mathrm{pH}$, esta característica deve ser considerada. A qualidade de conservação de pré-secado cortado sob as mesmas condições do feno, apresenta composição química semelhante ao feno, portanto, quando o pré-secado é preservado sob condições ideais, é uma alternativa a substituir o feno. A definição e as características do pré-secado expressa claramente que é uma conservação alternativa ao feno e a silagem.
\end{abstract}

Palavras-chave: Conservação. Desidratação. Fermentação. Forragem.

\section{INTRODUCTION}

The tropical regions present a well-defined dry season, which predisposes to a considerable fall in the availability and quality of the pastures, thus causing direct losses on cattle

\footnotetext{
${ }^{1}$ Federal University of Paraíba, Areia, Paraíba - Department of Zootecnia

${ }^{2}$ Federal University of Bahia, Salvador, Bahia - Department of Animal Science
} 
farming (BARCELOS et al., 2018). The forage comprises the main source of roughage (ZOU et al., 2016). Among the most cultivated forages in Brazil there are the genera Urochloa, Panicum, Pennisetum, Cynodon and Andropogon (CAVALCANTI et al., 2016).

The use of forage conservation methods to supply roughage to herbivores at critical times of production is an excellent strategy in animal production. Giving that the main ones are hay, silage and haylage, these require peculiar characteristics to be conserved. In the present study, it was found that most of the tropical grasses may not present such characteristics as soluble carbohydrates between 8 and 10\% (MCDONALD et al., 1991) for silage or have a high leaf:stem ratio (SILVA et al., 2011) which are common in the genus Cynodon, recommended for hay making. It can be adopted another form of conservation used in grasses, such as haylage, which corresponds to similar characteristics in the process of hay making (wilting and baling) and silage (conserved anaerobically).

Preserved in an anaerobic environment, haylage goes through fermentation without the presence of air and a decomposition that gradually changes its chemical composition leading to a qualitatively different product (BERGERO; PEIRETTI, 2011). However, it aims to keep quality close to forage in natura.

The objective whit this paper was to cover and discuss the characteristics of haylage that makes it an alternative of forage conservation.

\section{DEFINITION OF HAYLAGE}

The haylage is based on the dry matter (DM) content after a wilting process, then baled similar to hay and wrapped with plastic films in order to be conserved under anaerobic fermentation. According to Müller (2005) the DM content after wilt exceeds $500 \mathrm{~g} \mathrm{~kg}^{-1}$, Costa et al. (2018) attributed its definition to a variation of DM from 500 to $750 \mathrm{~g} \mathrm{~kg}^{-1}$.

Analyzing the DM concentrations of silage which according to McDonald et al. (1991) are from 300 to $350 \mathrm{~g} \mathrm{~kg}^{-1}$ and the low moisture content of hay thatfor Sampaio et al. (1997) varies between 10 and $18 \%$ for grasses, haylage is different because it presents intermediate DM contents at the time of preparation after dehydration.

The reduction in the moisture content is required for the production of haylage.This is carried out by conditioning (cutting, lining and drying for four to 24 hours) and depends on the moisture content and conditions of the forage, as wilting is necessary to reduce the moisture content to 40 to $60 \%$ (SCHROEDER, 2013). This is a hybrid method of forage conservation (PEDREIRA, 2010). And when these different DM concentrations of the forage mass are obtained at each harvest stage, it will affect the weight change of the bale (HAN et al., 2014). 


\section{FERMENTATIVE CHARACTERISTICS OF HAYLAGE}

\section{Haylage Microbiological Counts}

High counts of enterobacteria, yeasts and molds may be of greater interest once their presence in the pre-conserved crop may negatively influence the hygiene quality and stability of haylage aerobic storage (SCHENCK; MÜLLER, 2013). As it can be seen in table 1, there is a brief survey of microbiological counts in haylage, which has fundamental importance in the qualitative evaluation. The first stage after confection is the competition between epiphytic microorganisms to use soluble carbohydrates and produce fermentation products, at this stage undesirable microorganisms such as enterobacteria, clostridia and fungi also grow, causing nutritional losses (RIDWAN et al., 2015). Homofermentative bacteria improve the conservation by accelerating the initial phase of the process through the fermentation of water-soluble carbohydrates into lactic acid with a rapid subsequent decrease in pH (NI et al., 2015).

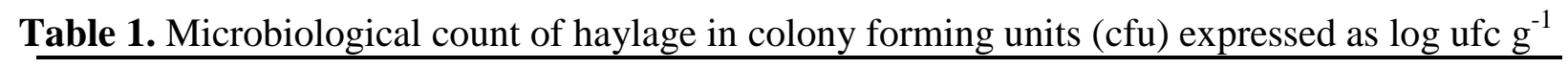

\begin{tabular}{ccccccc}
\hline pH & Clostridium & Yeast & Mold & Enterobacteria & LAB & Author \\
\hline 5.37 & 5.99 & --- & --- & 2.01 & 5.83 & 1 \\
5.04 & 2.13 & 1.03 & 4.47 & -- & --- & 2 \\
--- & 1.64 & 4.96 & 1.26 & 1.48 & 4.53 & 3 \\
5.58 & $<1.5$ & 6.12 & $<1.5$ & 1.5 & 5.49 & 4 \\
\hline
\end{tabular}

Source: Compiled from 1: Nath et al. (2018), 2: Arriola et al. (2015), 3: Schenck; Müller (2013) and 4: Müller (2009). LAB: lactic acid bacteria.

To minimize the risk of clostridium fermentation, the plant must be wilted to reach a dry matter content of more than $30 \%$ before being ensiled, as clostridia are less likely to dominate the silage process in drier forages because they do not tolerate high osmotic pressures (KUNG JR et $a l ., 2010)$. Forages conserved with high content of dry matter confer stabilization at high $\mathrm{pH}$, this favors bacteria of the genus Clostridium (MOTA et al., 2011). Which, also explains the counts of enterobacteria, as these are sensitive to low pH (ÖSTLING; LINDGREN, 1995).

Fungi and yeast may degrade the residual sugars and the lactic acid produced in the anaerobic phase (MCDONALD et al., 1991). The hermetic seal is the key factor in preventing the development of fungi and other aerobic pathogens in bales. Although the use of bales has been proposed as an alternative practice of forage storage where production is challenging, advancedstage forage storage packed in individual bales is occasionally vulnerable to deterioration due to poor fermentation (HAN et al., 2014). 
The minimum lactic acid bacteria (LAB) counts is $5 \log \mathrm{cfu} \mathrm{g}^{-1}$, as recommended by Muck (1996). The increase in the LAB population generally increases the concentration of lactic acid (RIDWAN 2015). Two of the three studies cited above (Table 1) present a minimum acceptable count.

\section{Main Fermentations}

The main haylage fermentations are listed in Table 2. Ammoniacal nitrogen $\left(\mathrm{NH}_{3}\right)$ can be influenced by the crude protein contents present in the forages at the time of cutting, since this variable is expressed as total nitrogen concentration (PINHO et al. al., 2013). The minimum value recommended for this variable, according to McDonald et al. (1991) is $10 \%$. The $\mathrm{NH}_{3}$ contents are within the recommended range.

Table 2. Haylage fermentative characteristics

\begin{tabular}{cccccccc}
\hline \multirow{2}{*}{ Species } & \multirow{2}{*}{$\mathbf{N H}_{3}$} & \multicolumn{7}{c}{ Organic acids } & \multirow{2}{*}{ Author } \\
\cline { 3 - 7 } & & $\mathbf{p H}$ & Lactic & Acetic & Propionic & Butyric & \\
\hline Tifton $85^{*}$ & 2.46 & 6.04 & 2.15 & 0.55 & 0.06 & 0.02 & 1 \\
${\text { Tifton } 85^{* *}}^{* *}$ & 1.25 & 5.21 & 2.39 & 0,13 & 0.002 & 0.02 & 2 \\
Ryegrass $^{* *}$ & $37^{* * *}$ & 5.90 & 0.0 & 3.70 & 0.00 & 0.00 & 3 \\
\hline
\end{tabular}

Source: Compiled from 1: Bernard et al. (2010), 2: Costa et al. (2018) and 3: Bergero et al. (2002).

$\mathrm{NH}_{3}$ : ammoniacal nitrogen; ${ }^{*}$ Values as a percentage of dry matter; ${ }^{* *}$ Values as $\mathrm{g} \mathrm{kg}^{-1}$ of dry matter, ${ }^{* * *} \mathrm{~g} \mathrm{~kg}^{-1}$ of total nitrogen.

Tifton 85 subjected to $523 \mathrm{~g} \mathrm{~kg}^{-1}$ of dry matter has limited sugar concentrations, the fermentation was not extensive, resulting in a $\mathrm{pH}$ higher than normally expected, but there were no visible signs of deterioration (BERNARD et al., 2010). The development of these microorganisms is directly linked to $\mathrm{pH}$, and in silage, growth inhibition is observed when the $\mathrm{pH}$ is 5.2, however, its viability loss occurs only at more acidic pH (SCHOCKEN-ITURRINO et al., 2005). It should be noted that the $\mathrm{pH}$ of the haylage, because it has a high content of dry matter in the confection, limits the capacity of bacterial fermentation, as it does not produce sufficient acid and becomes resistant to the $\mathrm{pH}$ drop, this characteristic must be considered along with other factors, such as forage buffer capacity. Therefore, the pattern used to evaluate haylage fermentation parameters should be different from those recommended for silage (COSTA et al., 2018)

High levels of acetic acid occur due to the presence of heterolactic bacteria and indicate undesirable changes during fermentation, causing a reduction in silage consumption by the 
animals (NATH et al., 2018). Müller (2011) observed levels of 7.6 and $2.5 \mathrm{~g} \mathrm{~kg}^{-1}$ in the dry matter for lactic acid and acetic acid, 0.026 for $\mathrm{NH}_{3}$ of haylage total nitrogen preserved at $\mathrm{pH}$ 6.10 and did not observe biological importance for the digestive measures performed. Acetic and butyric acids are weaker than lactic acid, and the formation of butyric acid often costs 2 lactic acid molecules (COBLENTZ et al., 2016).

Usually the haylage is made using the whole plant. According to Müller (2009) the management of the conservation and aerobic stability of the storage of haylage of whole plant can be a challenge regarding the achievement and maintenance of a high hygienic quality of the forage, and a method to improve the fermentation and hygienic quality of the haylage is to mechanically cut the forage before making it. Providing simple and workable strategies that improve the final product, is convenient.

\section{CUTTING POINT AND HAYLAGE CONSUMPTION}

Müller (2011) observed that grass harvested at different ages cut in June, July and August from the same primary growth, differed in chemical composition, with the earliest harvest containing the least amount of fiber and lignin, while the opposite occurred at harvest of August. The preservation quality of haylage cut under the same conditions of the hay, has chemical composition similar it, except for crude protein and crude energy, which were higher than hay, therefore, when haylage is well preserved, it is an alternative to replace hay (BERGERO, 2011).

Grasses in a more advanced stage tend to have a higher proportion of leaf:stem ratio getting more support tissues and less cell content, so the quality of haylage is lower compared to the cut in the hay stage (Table 3).

Table 3. Dry matter (DM), crude protein (CP), neutral detergent fiber (NDF), acid detergent fiber (ADF) and organic matter (OM) as $\mathrm{g} \mathrm{kg}^{-1} \mathrm{DM}$ in haylage of Tifton 85 (Cynodon spp.)

\begin{tabular}{cccccccc}
\hline DM & CP & NDF & ADF & OM & Cutting $^{1}$ & Opening $^{2}$ & Author $^{2}$ \\
\hline 536.5 & 59.9 & 783.7 & 446.7 & 935.6 & Advanced $^{3}$ & --- & 1 \\
513 & 188 & 691 & 321 & --- & 28 & 112 & 2 \\
704.6 & 142.1 & 779.5 & 346.6 & 916.7 & 30 & 56 & 3 \\
\hline
\end{tabular}

Source: Compiled from 1: Souza et al. (2006), 2: Arriola (2015) and 3: Costa (2018).

${ }^{1}$ Days, ${ }^{2}$ days after wrapping (closure), ${ }^{3}$ advanced growth stage.

The advance in age leads to an increase in the levels of structural carbohydrates and lignin, besides reducing nutrients that are potentially digestible of the forage plant. These factors 
negatively influence the nutritive value, reflecting in the consumption and digestibility of the forage, affecting animal production (CAVALCANTI et al., 2016).

According to Bernard et al. (2010) Tifton 85 can be used to supply up to $12.5 \%$ of the diet DM, without affecting the dry matter intake or production of high performance lactating Holstein cows, when diets are formulated to provide similar concentrations of NDF. It can also be associated with sorghum silage without compromising the consumption and digestibility of beef cattle (PEREIRA et al., 2007). However, it is crucial that the cutting is performed similar to that used in the normal management of each pasture or similar regrowth time for hay making. Müller (2011) found that a late harvest for haylage can prolong the feeding time for horses due to a longer feeding time per $\mathrm{kg}$ of DM for that haylage.

\section{FINAL CONSIDERATIONS}

The definition and characteristics of haylage clearly express that it is an alternative conservation to hay and silage.

There is variation in the dry matter content after dehydration, and contents varying from 400 to $600 \mathrm{~g} \mathrm{~kg}^{-1}$ might be the most recommended.

In order to obtain haylage of quality near to in natura forage, it is crucial to consider the hay stage as the starting point at the ideal cutting time and that the fermentative characteristics are within the recommended at the time of opening.

\section{REFERENCES}

ARRIOLA, K.G. et al. Effect of microbial inoculants on the quality and aerobic stability of bermudagrass round-bale haylage. Journal of Dairy Science. v.98, n.1, 2015.

BARCELOS, A.F. et al. Valor nutritivo e características fermentativas da silagem de capimelefante com diferentes proporções de casca de café. Ciência Animal Brasileira. v.19, p.1-12, 2018. DOI: 10.1590/1809-6891v19e-27432.

BERGERO, D.; PEIRETTI, P.G. Intake and Apparent Digestibility of Permanent Meadow Hay and Haylage in Ponies. Journal of Equine Veterinary Science. v.31, p.67-71, 2011. Disponível em: http://dx.doi:10.1016/j.jevs.2010.12.006.

BERGERO, D.; PEIRETTI, P.G.; COLA, E. I ntake and apparent digestibility of perennial ryegrass haylage fed to ponies either at maintenance or at work. Livestock Production Science. v.77, p.325-329, 2002.

BERNARD, J.K. et al. Effect of feeding alfalfa hay or Tifton 85 bermudagrass haylage with or without a cellulase enzyme on performance of Holstein cows. Journal of Dairy Science. v.93, n.11, 2010. DOI:10.3168/jds.2010-3111. 
CAVALCANTI, A.C. et al. Consumo e digestibilidade aparente do feno de Andropogon gayanus colhido em três idades diferentes. Ciência Animal Brasileira. v.17, n.4, p.482-490, 2016. DOI: 10.1590/1089-6891v17i416026.

COBLENTZ, W.K.; COFFEY, K.P.; CHOW, E.A. Storage characteristics, nutritive value, and fermentation characteristics of alfalfa packaged in large-round bales and wrapped in stretch film after extended time delays. Journal of Dairy Science. v.99, n.5, 2016. Disponível em: http://dx.doi.org/10.3168/jds.2015-10380.

COSTA, M.L.L. et al. Fermentation pattern of tropical grass haylage and digestibility compared to hay in equine diet. Semina: Ciências Agrárias. v.39, n.5, p.2125-2132, 2018. DOI:

10.5433/1679-0359.2018v39n5p2125.

HAN, K.J. et al. Bale Location Effects on Nutritive Value and Fermentation Characteristics of Annual Ryegrass Bale Stored in In-line Wrapping Silage. Asian-Australas Journal of Animal Sciences. v.27, n.9, p.1276-1284, 2014. Disponível em: http://dx.doi.org/10.5713/ajas.2013.13814.

KUNG JR, L. et al. The effect of wide swathing on wilting times and nutritive value of alfalfa haylage. Journal of Dairy Science. v.93, n.4, 2010. DOI: 10.3168/jds.2009-2451.

MCDONALD, P.; HENDERSON, A.R.; HERON, S.J.E. The biochemistry of silage. 2.ed. Marlow: Chalcombe Publications, 1991. 340p.

MOTA, Á.D.S. et al. Perfil de fermentação e perdas na ensilagem de diferentes frações da parte aérea de quatro variedades de mandioca. Revista Brasileira de Zootecnia. v.40, n.7, p.1466$1473,2011$.

MUCK, R. Inoculant of silage and its effects on silage quality. In: Informational Conference with Dairy and Forage Industries. Proceedings... US Dairy Forage Research, 1996. p.43-52.

MÜLLER, C.E. Equine ingestion of haylage harvested at different plant maturity stages. Applied Animal Behaviour Science. v.134, p.144-151, 2011. Disponível em:

http://dx.doi:10.1016/j.applanim.2011.08.005.

MÜLLER, C.E. Fermentation patterns of small-bale silage and haylage produced as a feed for horses. Grass Forage Science. v.60, p.109-18, 2005.

MÜLLER, C.E. Long-stemmed vs. cut haylage in bales-Effects on fermentation, aerobic storage stability, equine eating behaviour and characteristics of equine faeces. Animal Feed Science and Technology. v.152, p.307-321, 2009. Disponível em:

http://dx.doi:10.1016/j.anifeedsci.2009.04.016.

NATH, C.D. et al. Characterization of Tifton 85 bermudagrass haylage with different layers of polyethylene film and storage time. Asian-Australas Journal of Animal Sciences. v.31, n.8, p.1197-1204, 2018. Disponível em: https://doi.org/10.5713/ajas.17.0604.

NI, K. et al. Characterization, Identification and Application of Lactic Acid Bacteria Isolated from Forage Paddy Rice Silage. PLoS ONE. v.10, n.3, p.1-14, 2015.

DOI:10.1371/journal.pone.0121967.

PEDREIRA, C.G.S. Gênero Cynodon. In: FONSECA, D.M.; MARTUSCELLO, J.A. (Eds.)

Plantas forrageiras. Viçosa, MG: UFV, 2010. p.78-130. 
PEREIRA, O.G. et al. Consumo, digestibilidade e parâmetros ruminais em bovinos de corte alimentados com dietas contendo silagem de sorgo e pré-secado de capim-tifton 85 . Revista Brasileira de Zootecnia. v.36, n.6, p.2143-2151, 2007.

PINHO, R.M.A. et al. Microbial and fermentation profiles, losses and chemical composition of silages of buffel grass harvested at different cutting heights. Revista Brasileira de Zootecnia. v.42, n.12, p.850-856, 2013.

RIDWAN, R. et al. Fermentation Characteristics and Microbial Diversity of Tropical Grasslegumes Silages. Asian-Australas Journal of Animal Sciences. v.28, n.4, p.511-518, 2015. Disponível em: http://dx.doi.org/10.5713/ajas.14.0622.

ROMERO, J.J.; ZARATE, M.A.; ADESOGAN, A.T. Effect of the dose of exogenous fibrolytic enzyme preparations on preingestive fiber hydrolysis, ruminal fermentation, and in vitro digestibility of bermudagrass haylage. Journal of Dairy Science. v.96, n.1, 2015. Disponível em: http://dx.doi.org/10.3168/jds.2014-8285.

SAMPAIO, A.O. et al. Conservação de forrageiras e pastagens. In: EMBRAPA - Centro Nacional de Pesquisa de Gado de Leite (Org.) Trabalhador na bovinocultura de leite: manual técnico, 1997. Belo Horizonte: SENARAR/MG/EMBRAPA, p.67-100.

SCHENCK, J.; MÜLLER, C.E. Microbial Composition before and after Conservation of GrassDominated Haylage Harvested Early, Middle, and Late in the Season. Journal of Equine Veterinary Science. p.1-9, 2013. Disponível em: http://dx.doi.org/10.1016/j.jevs.2013.11.005.

SCHOCKEN-ITURRINO, R.P. et al. Alterações Químicas e Microbiológicas nas Silagens de Capim-Tifton 85 após a Abertura dos Silos. Revista Brasileira de Zootecnia. v.34, n.2, p.464$471,2005$.

SCHROEDER, J.W. Haylage and Other Fermented Forages. North Dakota State University. 2013. Disponível em: https://www.ag.ndsu.edu/pubs/ansci/dairy/as1252.pdf. Acesso em: $10 \mathrm{de}$ novembro de 2018.

SILVA, E.B. et al. Componentes morfológicos e curva de desidratação de gramíneas tropicais. Tecnologia \& Ciência Agropecuária. v.5, n.3, p.43-46, 2011.

SOUZA, V.G. et al. Efeito da substituição de pré-secado de capim-tifton 85 por silagem de sorgo no consumo e na digestibilidade dos nutrientes e no desempenho de bovinos de corte. Revista Brasileira de Zootecnia. v.35, n.6, p.2479-2486, 2006.

ZOU, Y. et al. Effects of moisture content or particle size on the in situ degradability of maize silage and alfalfa haylage in lactating dairy cows. Animal Nutrition. v.2, p.249-252, 2016. Disponível em: http://dx.doi.org/10.1016/j.aninu.2016.05.002.

ÖSTLING, C.; LINDGREN, S. Influences of enterobacteria on the fermentation and aerobic stability of grass silages. Grass Forage Science. v.50, p.41-47, 1995. 